\title{
The State of Reproductive Medicine in Germany
}

\section{Stand der Reproduktionsmedizin in Deutschland}

Authors

Affiliation
K. Diedrich, T. Strowitzki, H. Kentenich

Clinic for Gynaecology and Obstetrics, Lübeck
Key words

- gynecological endocrinology and reproductive medicine

- research in this area

- waiting for a law in reproductive medicine

Schlüsselwörter

- gynäkologische Endokrinologie und Reproduktionsmedizin

- Forschung in Deutschland

- Warten auf Fortpflanzungsmedizingesetz received $\quad 31.1 .2012$

accepted 10.2.2012

Bibliography

DOI http://dx.doi.org/ 10.1055/s-0031-1298358

Geburtsh Frauenheilk 2012; 72:

225-234 ๑ Georg Thieme

Verlag KG Stuttgart · New York ISSN 0016-5751

\section{Correspondence}

Prof. Dr. Klaus Diedrich

Clinic for Gynaecology and Obstetrics

Ratzeburger Allee 160

23538 Lübeck

klaus.diedrich@uk-sh.de

\section{Abstract \\ $\nabla$}

In the 1960s and 70s, Germany played a leading role in the field of gynaecological endocrinology, which was reflected by the scientific activity of German universities during this period. More recently, however, a dramatic change occurred, resulting in a decreasing number of publications in this field. This has undoubtedly contributed to the marginal scientific position of Germany in gynaecological endocrinology today. This change is reflected by the decreasing number of university centres carrying out active scientific research in the fields of gynaecological endocrinology, reproductive medicine and andrology. Universities now lack mid- and upper-level faculty staff, as interesting and senior positions in the field of reproductive medicine, andrology and reproductive medicine no longer exist. Moreover, in 1991 the German embryo protection law came into force, which severely curtailed scientific research and blocked scientific efforts in this area. German scientists and, of course, childless couples were cut off from scientific advances, e.g. the possibility of single embryo transfer. Germany's scientific position in the fields of gynaecological endocrinology, reproductive medicine and andrology needs to be strengthened. The creation of appropriate structures in German universities is therefore necessary. These would include important cooperations with private medical practices, which currently account for about $75 \%$ of patient care. The lines of communication between the groups representing reproductive medicine in Germany need to be greatly improved. Moreover, we suggest that an important step would be the development of a general human embryology and fertilisation act which would allow German couples to benefit from the global advances in the field of reproductive technology. Germany must stop its policy of scientific obstruction and permit scientific progress in this field in German universities.

\section{Zusammenfassung \\ $\nabla$}

Deutschland hat in den 1960er- und 70er-Jahren weltweit im Bereich der gynäkologischen Endokrinologie eine führende Rolle gespielt. Dies spiegelt sich auch wider in den wissenschaftlichen Aktivitäten im Bereich der deutschen Universitäten. In den letzten Jahren hat sich dies dramatisch geändert. Es zeigt sich in einem abnehmenden publizierten Forschungsoutput, in dem Deutschland im Gegensatz zu früher eine Randstellung einnimmt. Dies geht einher mit einer abnehmenden Präsenz der Bereiche Endokrinologie, Reproduktionsmedizin und Andrologie an den Universitäten. Es ist zu einem Verlust des akademischen Ober- und Mittelbaus an den Universitäten gekommen, da an den Universitäten keine entsprechenden zukunftsträchtigen Positionen und Perspektiven geboten werden konnten. Darüber hinaus wirkt auch das seit 1991 bestehende Embryonenschutzgesetz in vielen Bereichen der Reproduktionsmedizin eher forschungshemmend. Dies hat dazu geführt, dass die deutschen Forscher und damit auch die kinderlosen Paare am Fortschritt der Reproduktionsmedizin, wie z.B. beim Single Embryo Transfer, nicht teilhaben können. Der Forschungsstandort Deutschland im Bereich der Reproduktionsmedizin, Endokrinologie und Andrologie muss gestärkt werden. Dazu müssen an den Universitäten entsprechende Strukturen geschaffen werden, und es muss die Vernetzung zwischen den niedergelassenen Praxen, in denen 75\% der Patientenbehandlungen im Bereich der Reproduktionsmedizin stattfindet, und den Universitäten gefördert werden. Es muss deshalb der Kontakt zwischen den verschiedenen Gruppierungen, die in Deutschland die Reproduktionsmedizin vertreten, verbessert werden. Darüber hinaus muss ein Fortpflanzungsmedizingesetz erarbeitet werden, das es ermöglicht, auch die deutschen Paare an den Fortschritten der Reproduktionsmedizin teilhaben zu lassen. Es kann nicht sein, dass Deutschland auf einer einsamen Insel lebt und um uns herum der Fortschritt in diesem wichtigen Bereich der Medizin blüht. 


\section{Introduction}

Few areas in medicine have experienced such rapid progress over the past 40 years as reproductive medicine. These advances have not only benefitted science all over the world, but also the couples who were treated.

This paper is a critical positioning of current reproductive medicine in Germany.

\section{Research in Reproductive Medicine in Germany}

From the beginning of the previous century, Germany has played a leading role in human endocrinology and reproductive medicine research. Few areas in the medical field have shown such rapid progress and development as reproductive medicine and endocrinology. Some of the most significant milestones are provided below ( $\odot$ Table 1 ).

The considerable research activity during the 1970s and 80s in Germany in the fields of endocrinology and reproductive medicine led to a high profile of these areas in universities and the establishment of departments dedicated to gynaecological endocrinology, reproductive medicine and andrology.

The German government has supported these areas since 1991 with two major research programmes. Active research groups also received support from the German Research Foundation (DFG). In addition to contributing to progress in research and scientific expertise, these events also benefitted many childless couples who had previously been hopeless. Up to 2006, 3.9 million children worldwide were born through in vitro fertilisation and ICSI (intracytoplasmic sperm injection). In Germany alone, over 150000 children were born by this assisted method since 1982 . During the last few years, a dramatic change has taken place, reflected also in the decrease of published research output. Germany is increasingly taking a marginal role, as can be seen in the diminishing number of contributions to international journals (with peer reviews) and annual conferences. This trend is accompanied by a decrease in the presence of endocrinology, reproductive medicine and andrology at universities.

Universities are losing their upper and middle-level academics since they are no longer able to offer positions with good prospects. At the same time, about 100 private centres have been opened, which provide the majority of treatments in reproductive medicine but do not engage in research projects. Universities

Table 1 Development in reproductive medicine.

\begin{tabular}{ll}
1960 & $\begin{array}{l}\text { Radioimmunoessays for hormone level measurement } \\
\text { Ovarian stimulation with clomiphene and gonadotropins }\end{array}$ \\
\hline 1970 & $\begin{array}{l}\text { Secretion, synthesis and mechanism of GnRH and gonadotropins } \\
\text { In vitro fertilisation and embryo transfer }\end{array}$ \\
\hline 1980 & $\begin{array}{l}\text { GnRH agonists and gonadotropin } \\
\text { Cryoconservation of embryos and oocytes }\end{array}$ \\
\hline 1990 & $\begin{array}{l}\text { Recombinant gonadotropin } \\
\text { Preimplantation genetic diagnosis } \\
\text { Intracytoplasmic sperm injections (ICSI) } \\
\text { GnRH antagonists and gonadotropin }\end{array}$ \\
& In vitro maturation of egg cells (IVM) \\
& Vitrification of embryos and egg cells \\
& Embryo stem cells \\
& Single embryo transfer (SET)
\end{tabular}

\section{Einleitung}

$\nabla$

Es gibt nur wenige Gebiete in der Medizin, in denen der Fortschritt so rapide gelaufen ist wie in der Reproduktionsmedizin in den letzten 40 Jahren. Davon hat nicht nur die Wissenschaft weltweit profitiert, sondern auch die Paare, die wir als Ärzte betreuen.

In dem nachfolgenden Papier wird eine kritische Standortbestimmung der Reproduktionsmedizin in Deutschland vorgelegt.

\section{Forschung im Bereich der Reproduktionsmedizin in Deutschland \\ $\nabla$}

Deutschland hatte seit dem Beginn des vorherigen Jahrhunderts eine herausragende Rolle in der Forschung der menschlichen Endokrinologie und Reproduktionsmedizin gespielt. Es gibt nur wenige Bereiche in der Medizin, in denen Fortschritt und Entwicklung so schnell abgelaufen sind wie in der Reproduktionsmedizin und Endokrinologie. Einige dieser wichtigen Meilensteine sind nachfolgend aufgeführt ( Tab. 1):

Auch in Deutschland zeigte sich in den 70er- und 80er-Jahren im Bereich der Endokrinologie und Reproduktionsmedizin starke Forschungsaktivität, sodass sich an den Universitäten eine hohe Repräsentanz ergab, die sich in der Einrichtung einer Reihe von Abteilungen für gynäkologische Endokrinologie, Reproduktionsmedizin und Andrologie niederschlug.

Die Bundesregierung unterstützte seit 1991 diese Bereiche mit 2 großen Forschungsprogrammen. Einen Überblick über die DFG-geförderten Forschungen zeigte ebenfalls, dass aktive Forschungsgruppen eine Förderung erhielten.

Neben dem Fortschritt in der Forschung und dem wissenschaftlichen Erkenntnisgewinn konnten auch viele bis dahin hoffnungslos ungewollt kinderlose Paare von dieser Entwicklung profitieren. Bis 2006 wurden weltweit 3,9 Mio. Kinder nach assistierter Reproduktion, Invitro-Fertilisation und ICSI (intrazytoplasmatischer Spermieninjektion) geboren. Alleine in Deutschland wurden seit 1982 über 150000 Kinder nach diesen Behandlungen geboren. In den letzten Jahren hat sich eine dramatische Veränderung ergeben, die sich auch im abnehmenden, publizierten Forschungsoutput widerspiegelt. So nimmt Deutschland in diesem Bereich immer mehr eine Randstellung ein, die sich in der schrumpfenden Anzahl der Beiträge in den internationalen Zeitschriften (mit Peer-Review-Verfahren) und auf den Jahreskongressen zeigt. Dieses geht einher mit einer abnehmenden Präsenz der Bereiche Endokrinologie, Reproduktionsmedizin und Andrologie an den Universitäten.

Es ist zu einem Verlust des akademischen Ober- und Mittelbaus an den Universitäten gekommen, da an den Universitäten keine entsprechenden zukunftsträchtigen Positionen und Perspektiven geboten werden konnten. Parallel zu diesem Abbau an den Universitäten gab es die Gründung von etwa 100 niedergelassenen privaten Zentren, die mittlerweile den größten Teil der reproduktionsmedizinischen Behandlungen durchführen, ohne Forschungsaufgaben wahrzunehmen. Die Universitäten haben daher in der Patientenversorgung, welche die Grundlage auch für die Rekrutierung von Patienten für die Forschung ist, nur noch eine marginale Bedeutung. Hier spielt sicherlich auch die Problematik der kostendeckenden Therapie durch die Ermächtigungspolitik der kassenärztlichen Vereinigungen eine wichtige Rolle. Darüber hinaus wirkt auch in vielen Bereichen der Reproduktionsmedizin das seit 1991 bestehende Embryonenschutzgesetz eher forschungshemmend. An vielen neuen wissenschaftlichen Entwicklungen können deutsche Forscher nicht oder nur bedingt teil- 
are now only of marginal significance in patient treatment, which had been the basis for recruiting patients for research purposes. The situation has clearly also been fuelled by the approval policies of the Associations of Statutory Health Insurance Physicians to guarantee affordable treatment. Furthermore, the Embryo Protection Law passed in 1991 has restricted research in many areas of reproductive medicine. German researchers cannot participate or can only partially participate in many new scientific developments, for example: embryo stem cell research, pre-implantation diagnosis and single embryo transfer.

\section{Overview of Research Stimulus Programmes and Reproductive Medicine Research \\ $\nabla$}

The present overview takes into consideration the research stimulus programmes of the Federal Ministry of Education and Research (BMBF), as well as the projects of the German Research Foundation.

The current state of scientific activities can be gauged from a PubMed study spanning the years 1990 to 2006 based on the key word "Assisted Reproductive Technics" (Human), as well as the presence of German working groups at the ESHRE annual meeting (European Society of Human Reproduction and Embryology), in particular the 2008 meeting.

\section{Federal Government programmes}

The Federal Government has run two programmes. The initiative "Key research area: Fertility disorders" was supported by the Federal Ministry of Research from 1991 to 2000. A total of 30 projects with a value of 14.5 million euros were launched.

From 2005 to 2009, the use and risks in hormone replacement therapy as focal research area was evaluated at a cost of 5.1 million euros.

In the final analysis, the two programmes were politically driven. From 1990, in vitro fertilisation established itself as the fertility treatment of choice, being also conducive to studies into the reasons for infertility and concomitant research such as psychosomatics. This emphasis led to the focus on the extensive area of fertility disorders.

The controversy on hormone replacement therapy after the publication of the WHI and Million Women studies resulted in hormone replacement therapy becoming a key area of research. Fertility disorders and hormone replacement therapy became the only two focal areas of the German government from 1990.

\section{German Research Foundation}

A comprehensive overview of the German Research Foundation's activities in relation to human reproduction is not possible. From 1977 to 2009, support was given to certain groups active in the area of reproductive medicine.

The Max Planck Society research group conducted studies in human reproduction from 1981 to 1990 . This formed the basis for the Institute of Reproductive Medicine at the University of Münster.

Interestingly, other research institutes, such as the Leibniz Society and the Helmholtz Society, do not appear to conduct any research in human reproduction. nehmen, wie z.B. im Bereich der embryonalen Stammzellforschung, Präimplantationsdiagnostik und Single-Embryo-Transfer.

\section{Übersicht über Forschungsförderungsprogramme und durchgeführte Forschungen im Bereich der Reproduktionsmedizin} $\nabla$

Die Übersicht bezieht sich sowohl auf Forschungsförderungsprogramme des BMBF, die durch die DLR abgewickelt wurden, als auch auf die von der DFG geförderten Vorhaben.

Der aktuelle Stand der wissenschaftlichen Aktivitäten bezieht sich auf eine PubMed-Untersuchung der Jahre 1990 bis 2006 zum Stichwort „Assisted Reproductive Technics“ (Human), sowie die Präsenz der deutschen Arbeitsgruppen bei den ESHRE-Jahrestagungen (European Society of Human Reproduction and Embryology) und insbesondere der Jahrestagung 2008.

\section{Programme der Bundesregierung}

Es gab 2 Programme der Bundesregierung. Der „Forschungsschwerpunkt Fertilitätsstörungen“ wurde durch das BMF gefördert im Zeitraum von 1991 bis 2000. Insgesamt wurden 30 Vorhaben mit einem Volumen von 14,5 Mio. Euro gefördert.

Der Förderschwerpunkt Nutzen und Risiken der Hormonersatztherapie wird mit einem Volumen von 5,1 Mio. Euro in dem Zeitraum von 2005 bis 2009 gesehen.

In der Einschätzung handelt es sich um 2 Förderprogramme, die mit politischer Aktivität gewollt wurden. Ab 1990 hatte sich die Methode der In-vitro-Fertilisation als Methode zur Kinderwunschbehandlung etabliert, wobei hier eine Ursachenforschung für die Gründe der Sterilität, aber auch Begleitforschung, z.B. Psychosomatik, gefördert wurde. Aus diesem Grunde gab es den umfangreichen Förderschwerpunkt Fertilitätsstörungen.

Die Kontroversen über die Hormonersatztherapie nach der Veröffentlichung der WHI-Studie und der Million-Women-Studie haben zum Förderschwerpunkt Hormonersatztherapie geführt. Diese waren die einzigen Schwerpunkte der Bundesregierungszeit 1990.

\section{DFG-Forschung}

Ein kompletter Überblick über die DFG-Forschung im Bereich der menschlichen Reproduktion kann nicht erstellt werden. Ein Überblick der Jahre 1977 bis 2009 stellt dar, dass einige aktive Gruppen auf dem Gebiet der Reproduktionsmedizin gefördert wurden.

Die Max-Planck-Gesellschaft hat im Rahmen einer Forschungsgruppe 1981 bis 1990 Forschungen im Bereich der menschlichen Reproduktion gefördert. Dieses war die Basis für das Institut für Reproduktionsmedizin an der Universität Münster.

Auffallend ist, dass andere Forschungsinstitutionen wie die LeibnizGesellschaft oder Helmholtz-Gesellschaft offensichtlich im Bereich der menschlichen Reproduktion keine Forschung betreiben.

\section{Stiftungen}

Die Erfahrungen mit privaten Stiftungen zeigen, dass die menschliche Reproduktion von privaten Stiftungen nahezu nicht gefördert wird. Wir haben also einen Widerspruch zu sehen zwischen einer guten Verbreitung des Stiftungsgedanken in Deutschland und der geringen Akzeptanz, Forschungen im Bereich der Reproduktionsmedizin über private Stiftungen zu fördern. 


\section{Foundations}

Studies concerning private foundations show that research in human reproduction by these organisations received virtually no support. A contradiction exists between the well-diffused concept of the foundation in Germany and the low propensity to have reproductive medicine research conducted by foundations.

\section{German presence in publications}

A search for the key word "Assisted Reproduction" (PubMed 1990-2006) shows that German is in fifth place in Europe behind the United Kingdom and Belgium in terms of the number of publications. When considered in proportion to the number of inhabitants, German publications are only in thirteenth place in Europe. Seen in relation to the gross national product, Germany is again in thirteenth place. The ESHRE (European Society of Human Reproduction and Embryology) annual meeting of 2008 indicates a similar situation with regard to the contributions of German working groups.

ESHRE holds the world's leading congress, with 8000 participants recorded at the 2008 Barcelona meeting. Germany held tenth place at the 2008 meeting in terms of abstracts submitted. With regard to accepted presentations and accepted poster sessions, Germany was in ninth position. These results are disappointing and have become alarming over the past years considering the dropping German presence observed.

In a publication in 2000, Kremer et al. calculated the number of publications in the journals Fertility \&'Sterility and Human Reproduction according to country on the basis of gross national product, population and total number of publications. Germany did not make it into the top 10 in any of the above categories.

\section{Summary}

The German government has launched politically justified research programmes. Active working groups could obtain support from the German Research Foundation. This support is considered insufficient, and the scientific output of Germany in the area of human reproductive medicine is alarmingly low.

\section{University Structures}

Few universities offer key research areas in gynaecological endocrinology and reproductive medicine, or reproductive medicine and andrology. A few universities have working groups. A large number of universities do not provide for the treatment of couples in the area of reproductive medicine.

This is in clear contrast with the three-pronged programme of the German Society of Gynaecology and Obstetrics. This programme envisages an autonomous representation in universities of gynaecology and obstetrics, gynaecological endocrinology and reproductive medicine. Evidently this three-pronged programme is not being sustained.

The same fees for patient care by universities apply to all basic therapies such as stimulation with insemination, in vitro fertilisation and ICSI. However, for many years it was difficult to allow universities the authority to bill directly for reproductive medical treatment. Universities have been in direct competition with private service providers in individual centres, which have been preferred over universities. However, new developments concerning the establishment of medical care centres or ambulant surgery have made it possible for universities today to appropriately charge for reproductive medical interventions.

\section{Deutsche Präsenz im Bereich der Publikationen}

Eine Übersicht über die Publikationen zum Stichwort „Assistierte Reproduktion“ (PubMed 1990-2006) zeigt, dass bezogen auf die Anzahl der Veröffentlichungen Deutschland in Europa Platz 5 hinter dem Vereinigten Königreich und Belgien belegt. Bezieht man diese Übersicht auf die Einwohnerzahl, so liegt Deutschland im europäischen Vergleich nur auf Platz 13. Bezieht man dieses auf das Bruttosozialprodukt, liegt Deutschland ebenfalls nur auf Platz 13. Die Übersicht über die Beiträge von deutschen Arbeitsgruppen bei der ESHRE-Jahrestagung 2008 zeigt ein ähnliches Bild.

Die European Society of Human Reproduction and Embryology (ESHRE) ist die europäische Gesellschaft für Reproduktion. Ihr Jahreskongress dürfte der weltweit führende Kongress sein mit einer Teilnehmerzahl von zuletzt 8000 beim europäischen Kongress in Barcelona 2008. Eine Übersicht über die eingereichten Abstracts für den Jahreskongress 2008 zeigt Deutschland auf Platz 10. Bei den akzeptierten, freien Vorträgen liegt Deutschland auf Platz 9 und bei den akzeptierten Postern ebenfalls auf Platz 9. Diese Ergebnisse sind enttäuschend und vom zeitlichen Verlauf der letzten Jahre her beängstigend wegen des zu verzeichnenden Rückgangs der deutschen Präsenz.

Kremer et al. publizierten 2000 eine Arbeit, in der die Zahl an Publikationen in den Journalen Fertility \& Sterility und Human Reproduction nach Ländern ausgewertet wurde, wobei eine Nominierung nach Bruttosozialprodukt, nach Einwohnerzahl und Gesamtzahl an Publikationen des jeweiligen Landes durchgeführt wurde. In keiner der genannten Auswertungskategorien war Deutschland unter den Top $10 \mathrm{zu}$ finden.

\section{Resümee}

Die Bundesregierung hat politisch gewollte Forschungsprogramme aufgelegt. Aktive Arbeitsgruppen konnten eine Förderung über die DFG erhalten. Diese Förderung ist als unzureichend zu betrachten, und der wissenschaftliche Output für Deutschland im Bereich der menschlichen Reproduktionsmedizin ist besorgniserregend schlecht.

\section{Strukturen an den Universitäten}

$\nabla$

Nur in einer geringen Zahl von Universitäten gibt es Forschungsschwerpunkte für gynäkologische Endokrinologie und Reproduktionsmedizin oder Reproduktionsmedizin und Andrologie. Einige weitere Universitäten haben Arbeitsgruppen. Ein großer Teil der Universitäten sieht die Behandlung für Patientenpaare im Bereich der Reproduktionsmedizin nicht vor.

Dieses steht im deutlichen Widerspruch zu dem 3-Säulen-Programm der deutschen Gesellschaft für Gynäkologie und Geburtshilfe. Dieses Programm sieht eine selbstständige Repräsentanz an den Universitäten für Gynäkologie \& Geburtsmedizin, sowie gynäkologische Endokrinologie und Reproduktionsmedizin vor. Offensichtlich wird dieses 3-Säulen-Programm jedoch nicht durchgehalten.

Bez. der Vergütung der Patientenversorgung im Bereich der Universitäten lässt sich festhalten, dass die wesentlichen therapeutischen Verfahren wie Stimulation mit Insemination, In-vitro-Fertilisation und ICSI eine gleiche Vergütung erfahren. Jedoch war es lange Jahre schwierig, den Universitäten über eine persönliche Ermächtigung leistungsgerechte Abrechnungsmöglichkeiten für reproduktionsmedizinische Behandlung zu ermöglichen. Hier standen die Universitäten immer im direkten Wettbewerb mit den privaten Anbietern im niedergelassenen Bereich, die gegenüber den Universitäten bevorzugt wurden. Neue Entwicklungen über die Einrichtung eines medizinischen Versorgungszentrums oder das ambulante Operieren 
Therefore, inconsistent reimbursement should no longer be the reason for a lack of focal point and insufficient patient numbers. In reproductive medicine, many costs are covered by patient participation (in the case of public health insurance), self-pay patients (e.g. cryoconservation in pronuclear stage, sperm and testicular tissues) and IGeL individual health services (e.g. for assisted hatching). This additional source of income is equally available to private and university centres.

In the summer of 2008, a survey was conducted of the working groups for endocrinology and reproductive medicine in German universities (led by Dr. Thaler).

Responses from only 15 universities were collected. It was apparent that only a minority of the departments were autonomously managed in terms of W2 or W3 departments. The average number of medical personnel per working group was only $1-2$ staff members.

$93 \%$ of centres had been given permission by regional authorities to conduct artificial insemination. Most of these centres (66\%) billed more for artificial inseminations than ambulant surgery. The vast majority were not subject to restrictions by the Association of Health Insurance Physicians. The average number of IVF punctures was approximately 200 per year. Five of the university centres performed more than 400 IVF punctures per year.

In terms of scientific output, each working group published about seven articles in Anglo-American countries (peer review) and four to five publications in German-speaking countries. On average, each group achieved one accepted poster session or presentation at an ESHRE annual congress and three to four accepted presentations at the German Society of Gynaecology and Obstetrics (DGGG) annual congress.

\section{Summary}

1. The structural prerequisites in universities for an autonomous management and establishment of W2/W3 departments clearly need improvement.

2. There are no longer any substantial restrictions by regional authorities or the Association of Health Insurance Physicians.

3. Considering the low personnel numbers in working groups, scientific output is relatively good.

\section{Structure of Reproductive Medicine in Germany \\ $\nabla$}

Patient access to reproductive medicine in Germany is largely controlled by provisions governing public health insurance patients. These provisions are set out in German Social Security Code V, paragraph 27a and paragraph 121 a. According to these provisions, only physicians who have permission from the regional authorities are able to offer reproductive medical services to public insurance patients. Comprehensive general care and authorisation regulations have in the meantime been applied to the centres, but this does not lead to the assumption that these authorisations will be extensively raised in the near future.

Professional prerequisites are set out in the directives of the German Medical Association for Assisted Reproduction (2006). The prerequisites are set out primarily as guidelines. They are only applicable in the regional medical associations which consider the guidelines to be a part of their professional regulations.

Quality of care is recorded in the German IVF register (DIR). This is a voluntary collective record with no official authority. To date, the possibility of a quality test by regional authorities according machen jedoch heute auch für Universitäten die leistungsgerechte Abrechnung der reproduktionsmedizinischen Maßnahmen möglich. Dementsprechend müssen ungleiche Vergütungen nicht mehr die Ursache für die mangelnde Schwerpunktsetzung und ungenügende Patientenzahl sein.

Im Bereich der Reproduktionsmedizin wird vieles über Patientenbeteiligungen (bei gesetzlichen Krankenversicherten), über Selbstzahlerleistungen (z. B. Kryokonservierung von Vorkernstadien, von Spermien und testikulärem Gewebe) und über IGeL-leistungen (z. B. Assisted Hatching) abgerechnet. Diese zusätzlichen Einnahmequellen stehen privat geführten Zentren und universitären Zentren gleichermaßen zu.

Eine aktuelle Umfrage wurde im Sommer 2008 an die Arbeitsgruppen für Endokrinologie und Reproduktionsmedizin der Universitäten in Deutschland gerichtet (Federführung Prof. Dr. med. Thaler):

Es liegen die Antworten von nur 15 Universitäten vor. Darin zeigt sich, dass nur eine Minderheit der Abteilungen eine eigenständige Leitung im Sinne einer W2-oder W3-Abteilung hat. Die durchschnittliche Zahl der ärztlichen Mitarbeiter pro Arbeitsgruppe beträgt nur 1-2 Mitarbeiter.

Ordnungsbehördlich haben 93\% der Zentren eine Zulassung durch die Landesbehörde für Maßnahmen der künstlichen Befruchtung. Die Mehrheit dieser Zentren (66\%) rechnet diese Behandlung über das ambulante Operieren ab. Bei der großen Mehrheit der Zentren liegen keine Restriktionen seitens der KV vor. Vom Leistungsaufkommen her liegt die durchschnittliche Zahl der IVF-Punktionen bei ca. 200 pro Jahr. Fünf der universitären Zentren haben mehr als 400 Punktionen pro Jahr.

Bezüglich des wissenschaftlichen Outputs liegen pro Arbeitsgruppe im Jahr ca. 7 Arbeiten im angloamerikanischen Sprachraum vor (Peer-Review-Verfahren), 4-5 Publikationen im deutschsprachigen Raum pro Arbeitsgruppe und durchschnittlich ein akzeptierter Postervortrag oder freier Vortrag beim ESHRE-Jahreskongress und ca. 3-4 akzeptierte Vorträge auf den Jahreskongressen der DGGG.

\section{Resümee}

1. Die strukturellen Voraussetzungen an den Universitäten für eine selbstständige Leitung und Einrichtung von W2/W3-Abteilungen sind deutlich verbesserungsbedürftig.

2. Seitens der Behörden (Landesbehörden) und der KV liegen keine wesentlichen Restriktionen mehr vor.

3. Gemessen an der knappen personellen Ausstattung der Arbeitsgruppen ist der wissenschaftliche Output als relativ gut einzustufen.

\section{Strukturierung der Reproduktionsmedizin in Deutschland \\ $\nabla$}

In Deutschland ist der Patientenzugang zur Reproduktionsmedizin im Wesentlichen geregelt über die Vorschriften, welche die GKV-Patienten betreffen. Diese sind im Sozialgesetzbuch V geregelt über Paragraph 27a und Paragraph 121 a. In Deutschland darf dementsprechend nur derjenige Arzt Reproduktionsmedizin für GKV-Patienten anbieten, der eine Zulassung der Landesbehörde vorweisen kann. Da es mittlerweile zu einer flächendeckenden Versorgung und Zulassung der Zentren gekommen ist, ist nicht davon auszugehen, dass diese Zulassungen in der nächsten Zeit deutlich erhöht werden.

Die berufsrechtlichen Voraussetzungen sind in den Richtlinien der Bundesärztekammer zur assistierten Reproduktion (2006) geregelt. Diese Regelungen haben einen Richtliniencharakter. Sie sind nur in denjenigen Landesärztekammern berufsrechtlich anwendbar, bei denen die Richtlinien als Teil des Berufsrechts angesehen werden. 
to Section 121 a of the German Social Security Code has not been comprehensively applied.

\section{Possible Explanation for Problems in the Area of Human Reproduction Research in Germany $\nabla$}

\section{Political factors}

After the experience of Nazi dictatorship, all initiatives regarding human reproduction were met with reservations, which is understandable from a political standpoint. Similarly, legal provisions set out the restrictions of the Embryo Protection Law and Embryo Stem Cell Law.

The treatment of couples with infertility issues through reproductive medicine has increased in significance in recent years. Among the causes of this are social changes which have increased the average age at which women in industrialised countries experience their first pregnancy.

One of the objectives of reproductive medicine is to identify and treat the causes for infertility and, thereby, make pregnancy and childbirth possible. Health risks for the patients (couple and child) must be minimised. This must be done with constant reference to medical progress.

Reproductive medicine has made considerable advances in recent decades with regard to the effectiveness of procedures. However, even the most important risk, which is multiple pregnancy and constitutes high social risks for the mother and the danger of premature birth, can be considerably reduced today. This is achieved in the majority of European countries by using elective single embryo transfers (eSETs). The embryos produced in vitro are selected according to morphological criteria which favour implantation and a successful procedure. In patients with high risk of a multiple pregnancy, only the embryo which meets these criteria is chosen.

The Embryo Protection Law specifies that up to three embryos can be produced during one treatment cycle but that all embryos produced must be transferred. The Embryo Protection Law does not permit a selection of the embryos which have the greatest implantation chance and the exclusion of all other embryos in order to avoid the risk of multiple pregnancies.

Due to the Embryo Protection Law, reproductive medicine in Germany is no longer performed on a scientific and technical level, resulting in medical, ethical and legal, as well as personal and individual dilemmas for the affected couples. This should be addressed by a reproductive medicine law intended to find an appropriate compromise between the wishes of couples to have a child through reproductive medical means and the health and protection of the embryo; eSET should also be made possible.

As a result of employing eSET, however, a larger number of embryos capable of developing will be produced than were produced before. The surplus number of embryos with development potential should be preserved by cryoconservation for future treatment of the couple and should be destroyed after conclusion of the reproductive treatment. This process should be controlled by law. Any other uses of the embryos (e.g. for research) should remain prohibited.

Furthermore, a reproductive medicine law would cover other procedures which have hitherto remained unregulated or where loopholes exist, such as sperm donation and pre-implantation diagnosis as well as the control and supervision of reproductive medicine practices.
Die Qualität der Versorgung wird über das deutsche IVF-Register (DIR) erfasst. Hierbei handelt es sich um einen freiwilligen Zusammenschluss, der aber keine Ordnungsbefugnisse hat. Eine mögliche Überprüfung der Qualität über die Landesbehörden nach § 121 a SGB 5 wird zum jetzigen Zeitpunkt nicht flächendeckend ausgeübt.

\section{Mögliche Erklärung für die Probleme im Bereich der Forschung der menschlichen Reproduktionen in Deutschland \\ $\nabla$}

Politische Aspekte

Nach den Erfahrungen der Nazi-Diktatur wird allen Eingriffen in die menschliche Reproduktion der dementsprechenden Forschung mit Zurückhaltung begegnet - was politisch weiterhin nachvollziehbar ist. Die gesetzliche Fixierung findet sich entsprechend in den restriktiven Grundlagen des Embryonenschutzgesetzes und auch dem embryonalen Stammzellgesetz.

Die Gesundheitsversorgung von Paaren mit unerfülltem Kinderwunsch durch reproduktionsmedizinische Maßnahmen hat in den letzten Jahren zunehmend an Bedeutung gewonnnen. Eine der Ursachen liegt in den gesellschaftlichen Veränderungen, die das durchschnittliche Alter, in dem Frauen in den Industrienationen ihre erste Schwangerschaft anstreben, ansteigen lassen.

Ziel der Reproduktionsmedizin ist es, die Ursachen für eine Kinderlosigkeit zu erkennen, zu behandeln und so eine Schwangerschaft sowie die Geburt eines Kindes zu ermöglichen. Gesundheitsrisiken für die Patienten (Paar und Kind) sind dabei zu minimieren. Dies muss unter fortwährender Berücksichtigung des medizinischen Fortschritts erfolgen.

Die Reproduktionsmedizin hat sich in den vergangenen Jahrzehnten im Hinblick auf die Effektivität des Verfahrens erheblich weiterentwickelt. Aber auch das wichtigste Risiko, eine Mehrlingsschwangerschaft mit hohen gesellschaftlichen Gefahren für die werdende Mutter und meist zu früh geborenen Kinder, kann heute erheblich gesenkt werden.

Dies geschieht in der Mehrzahl der europäischen Staaten durch Anwendung des Verfahrens des elektiven Single-Embryo-Transfers (eSET). Die in-vitro-gezeugten Embryonen werden nach morphologischen Kriterien, die eine Implantationsfähigkeit und einen Behandlungserfolg erwarten lassen, ausgewählt, und es wird bei Patienten mit hohem Risiko für eine Mehrlingsschwangerschaft nur der Embryo implantiert, der diese Kriterien erfüllt.

Das Embryonenschutzgesetz legt dagegen fest, dass bis zu 3 Embryonen während eines Behandlungszyklus entstehen dürfen, alle entstandenen Embryonen aber auch transferiert werden müssen. Eine Auswahl des Embryos mit der größten Implantationschance, ohne dass alle entstandenen Embryonen mit dem Risiko der Mehrlingsschwangerschaft implantiert werden müssten, ist nach dem Embryonenschutzgesetz nicht möglich.

In Folge der Regelung des Embryonenschutzgesetzes findet die Reproduktionsmedizin in Deutschland nicht mehr auf dem Stand der medizinischen Wissenschaft und Technik statt - mit der Folge eines medizinischen, ethischen und rechtlichen und nicht zuletzt persönlichen, individuellen Dilemmas bei den betroffenen Paaren. Dieses sollte durch ein Fortpflanzungsmedizingesetz gelöst werden, das die Ziele - der Wunsch der Paare nach einem Kind durch fortpflanzungsmedizinische Hilfen und Gesundheitsschutz sowie der Schutz des Embryos - zu einem angemessenen Ausgleich bringt und den eSET ermöglicht.

Als Folge der Anwendung des Verfahrens des eSETs werden jedoch in größerem Ausmaß als bisher entwicklungsfähige Embryonen im 
An ethically indisputable solution which can be legally implemented is yet to be found. A process of weighing the options is available; however, this is not at the discretion of the individual but is based on fundamental rights underpinned by majority social consensus on reproductive medicine.

The challenge remains for responsible politicians to allow discussion and necessary development of the Embryo Protection Law or to supplement it with a reproductive medicine law.

\section{Economic aspects}

Studies have shown that in the estimated 100 working groups in Germany, the majority of group leaders qualified from universities.

Due to the lack of developmental or organisational opportunities at the universities in addition to poor financial prospects, over 100 privately run working groups focused on reproductive medicine have been established mostly under the leadership of these individuals.

Reproductive medicine is one of the most financially attractive areas of gynaecology since, in addition to payments via public health insurance, many services are either paid by private insurance or by the patients themselves (cryoconservation of egg cells, IGeL services). The generally high earning potential in privately run fertility centres and the lack of contributions by the universities to private medical cover have led to active researchers leaving the universities to work in private practices. Financial ambitions have prevailed over the original research ambitions. Furthermore, new contracts at university clinics are clearly further restricting the private health insurance possibilities for departmental heads.

A comparison with other countries shows that researchers in Sweden and Great Britain are also not among the best paid health professionals. It appears that their personal earnings come from creating publications, which creates the opportunities to participate in conferences abroad, ultimately forming the basis to later run scientific establishments.

Comparisons with foreign countries (including the USA) often show that university researchers in these countries simultaneously also have opportunities for financial gain at private institutes. This means that the division between the alternatives of attractive financial earnings and producing research reports is not as evident.

Research in the area of gynaecological endocrinology, reproductive medicine and andrology also involves basic research in order to better understand human reproductive medicine within its natural cycle. This research also includes studies of human reproduction disorders and the related care through the application of reproductive medical techniques. Preventive medical research as well as accompanying mental health, social and ethical research (e.g. in sperm, egg cell donation and embryo donation) are of fundamental importance. Questions about research in the field of human medicine, among others, are significant in strengthening the position of research in Germany.

\section{Future Considerations}

\section{$\nabla$}

Future considerations must be aimed at strengthening the position of research in Germany in the areas of reproductive medicine, gynaecological endocrinology and andrology. At the same time, research opportunities should be such that young researchers, in
Rahmen der Behandlung entstehen. Solche überzähligen Embryonen mit Entwicklungspotenzial sollten für weitere Behandlungen des Kinderwunschpaars kryokonserviert werden und müssen nach Abschluss der reproduktionsmedizinischen Behandlungsmöglichkeiten dem Absterbenlassen zugeführt werden. Dieses sollte gesetzlich geregelt werden. Eine fremdnützige Verwendung der Embryonen (z. B. Forschung) sollte verboten bleiben.

Darüber hinaus sollten in einem Fortpflanzungsmedizingesetz auch die anderen bisher ungeregelten und nur lückenhaft geregelten Verfahren wie die donogene Samenspende, die Präimplantationsdiagnostik, sowie die Kontrolle und Aufsicht über die Fortpflanzungsmedizin geregelt werden.

Eine ethisch unumstrittene Lösung, die rechtlich umgesetzt werden könnte, gibt es nicht. Es bleibt ein Abwägungsprozess, der aber nicht in das Belieben des Einzelnen gestellt sein sollte, sondern auf einer grundrechtlichen Basis vor dem Hintergrund des weitestgehenden gesellschaftlichen Konsens der Reproduktionmedizin stattfindet.

Die Aufforderung an die verantwortlichen Politiker bleibt bestehen, das Embryonenschutzgesetz einer Diskussion und einer notwendigen Weiterentwicklung zu unterziehen oder durch ein Fortpflanzungsmedizingesetz zu ergänzen.

\section{Ökonomische Aspekte}

Die Erfahrungen der etwa 100 Arbeitsgruppen Deutschlands zeigen, dass ein Großteil der Leiter dieser Arbeitsgruppen die Ausbildung an einer Universität erfahren hat.

Da diese Personen aber keine Entwicklungs-/Gestaltungsmöglichkeiten an Universitäten fanden und keine finanziell angemessenen Aussichten im Bereich der Universitäten vorhanden waren, haben sich über 100 privat geführte Arbeitsgruppen in Deutschland für die Reproduktionsmedizin, meist unter Leitung dieser Personen, gebildet.

Die Reproduktionsmedizin ist im Bereich der Gynäkologie eines der finanziell attraktivsten Felder, da neben der gesetzlichen Vergütung über die GKV viele Leistungen entweder privat abgerechnet werden oder auf Selbstzahlerbasis (Kryokonservierung von Eizellen, IGeLLeistung) abgegolten werden. Die in der Regel bedeutsamen Verdienstmöglichkeiten im Bereich der privat geführten Reproduktionszentren und die Nichtbeteiligung an der Privatliquidation an den Universitäten haben dazu geführt, dass aktive Forscher die Universität verlassen haben und nunmehr in der niedergelassenen Praxis tätig sind. Die finanziellen Ambitionen haben daher die ursprünglich vorhandenen Forschungsambitionen überlagert. Überdies schränken nunmehr die neuen Verträge die Liquidationsmöglichkeiten der Abteilungsleitung in den Universitätskliniken deutlich ein.

Ein Vergleich mit dem Ausland zeigt, dass Forscher in Schweden und Großbritannien auch nicht zu den bestbezahlten Medizinern gehören. Offensichtlich ziehen sie ihren persönlichen Gewinn aber daraus, dass sie über Veröffentlichungen die Möglichkeit haben, an Kongressen im Ausland teilzunehmen und dann später die Möglichkeit haben, wissenschaftliche Einrichtungen aufgrund einer guten Veröffentlichungspraxis zu leiten.

Oft zeigt ein Vergleich mit dem Ausland (USA ebenso), dass in anderen Ländern Forscher der Universitäten auch gleichzeitig finanzielle Verdienstmöglichkeiten an privaten Institutionen haben, sodass die trennende Alternative zwischen gutem finanziellem Verdienst und Forschungsberichten so nicht vorhanden ist.

Forschung im Bereich der gynäkologischen Endokrinologie, Reproduktionsmedizin und Andrologie betrifft sowohl Grundlagenforschung, um die menschliche Reproduktionsmedizin im natürlichen Zyklus besser verstehen zu können. Sie bezieht sich aber auch auf die Störung der menschlichen Reproduktions- und Versorgungsforschung bei der Anwendung reproduktionsmedizinischer Techniken. 
particular in universities, are offered good conditions in which to conduct their research activities and achieve positive outcomes.

We must also question whether the present Embryo Protection Law is too restrictive with regard to research in human reproductive medicine.

\section{Collaborative research}

Since patient access occurs primarily through individual, privately run centres and research is essentially conducted at universities, collaboration between the two structures is urgently needed.

Research associations should be formed which make use of the universities' background in scientific areas and guarantee patient access to private reproductive medicine centres.

The health services research programme of the German Medical Association can be taken as a model of how bridges can be built between private centres and university structures.

In a next step, urgent contact must be made with other associations also focused on reproductive medicine, such as the Federal Association of German Reproductive Medical Centres, the German Society for Reproductive Medicine and the German Society for Andrology. This challenge should be addressed and structures for launching research collaboration formed.

\section{University structures}

In Germany, the current availability of lecturing positions, departments and divisions in the area of reproductive medicine (as well as endocrinology and andrology) is drastically low. The relative professional associations (DGGG, DGRM, and DGA) should be approached to discuss the future creation of structures at universities in order to actively stimulate this branch of research.

The German Society for Gynaecology and Obstetrics should ask itself whether its three-pronged model is viable and whether it should be replaced by a model which will create interdisciplinary departments or centres for human reproduction that will comprise gynaecological endocrinology and reproductive medicine, andrology and human genetics, and accompanying psychosocial research.

Furthermore, the creation of lecturing positions, departments and divisions in the area of reproductive medicine, endocrinology and andrology should mean that these structures will be available to future scientists. It would be desirable for scientists to take leadership of these lecturing positions, departments and divisions, which in turn would stimulate research output. Lastly, the German Medical Association should consider whether the critical situation in reproductive medicine in Germany could be improved through the creation of a new interdisciplinary advanced education programme.

This should be discussed with the responsible professional associations (DGGG, DGRM, and DGA).

\section{Stimulation programmes}

The withdrawal of official stimulation programmes must be questioned and actively investigated.

Future steps may include:

1. Propose to the Health Research Council of the BMBW (and BMG) to include the concept of interdisciplinary reproductive medicine into the next health research programme.

2. Investigate the structures of the Max Planck, Helmholtz and Leibniz Societies in relation to opportunities for research in human reproduction.
Hierbei sind sowohl die anwendungsbezogene medizinische Forschung als auch die psychische, soziale und ethische Begleitforschung (z.B. bei der Samenspende, Eizellspende und Embryonenspende) wesentlich. Grundsätzlich haben Fragen der Forschung im Bereich der Humanmedizin, aber auch darüber hinaus, eine Bedeutung, um den Forschungsstandort Deutschland zu stärken.

\section{Überlegungen für die Zukunft \\ $\nabla$}

Die Überlegungen müssen zum Ziel haben, dass der Forschungsstandort Deutschland auch im Bereich der Reproduktionsmedizin, der gynäkologischen Endokrinologie und der Andrologie gestärkt werden muss. Zugleich sollen die Forschungsmöglichkeiten so gestaltet werden, dass junge Forscher insbesondere an den Universitäten gute Bedingungen finden, ihren Forschungsaktivitäten nachkommen zu können und sich dabei positiv entfalten zu können.

Hierzu muss auch hinterfragt werden, ob das jetzige Embryonenschutzgesetz im Bezug auf die Forschung der menschlichen Reproduktionsmedizin zu restriktiv ist.

\section{Vernetzung der Forschung}

Da der Patientenzugang in erster Linie flächenmäßig bei den niedergelassenen Zentren angesiedelt ist, die privat geführt werden und da die Forschung im Wesentlichen an Universitäten stattfindet, ist eine Vernetzung beider Strukturen dringend erforderlich.

Es sollten Forschungsverbände geschaffen werden, die den Hintergrund der Universitäten auf wissenschaftlichen Gebieten nutzen, wobei der Patientenzugang dann über die Zentren für Reproduktionsmedizin im niedergelassenen Bereich gewährleistet werden kann.

Das Programm der Bundesärztekammer zur Versorgungsforschung kann ein Vorbild sein, wie Brücken zwischen Niedergelassenen und universitären Einrichtungen geschlagen werden können.

In einem nächsten Schritt muss dringend Kontakt aufgenommen werden mit anderen Vereinigungen, die sich ebenfalls schwerpunktmäßig mit der Reproduktionsmedizin beschäftigen wie dem BRZ, der deutschen Gesellschaft für Reproduktionsmedizin und der deutschen Gesellschaft für Andrologie. Es müssen diese Probleme abgestellt und Strukturen zur Initiierung von Forschungsvernetzungen geschaffen werden.

\section{Strukturen der Universität}

Die aktuelle Präsenz von Lehrstühlen, Abteilung und Sektionen im Bereich der Reproduktionsmedizin (aber auch der Endokrinologie und Andrologie) in Deutschland ist dramatisch gering. Hier wäre über die entsprechenden Fachgesellschaften (DGGG, DGRM, DGA) zu klären, inwieweit in Zukunft Strukturen an den Universitäten geschaffen werden können, die diesen Forschungszweig aktiv fördern. Die deutsche Gesellschaft für Gynäkologie und Geburtshilfe muss sich fragen, ob ihr 3-Säulen-Modell tragfähig ist, und ob es durch ein Modell ersetzt wird, welches fächerübergreifend Sektionen oder Zentren für menschliche Reproduktion schafft, die gynäkologische Endokrinologie und Reproduktionsmedizin, Andrologie und Humangenetik und psychosoziale Begleitforschung ETC umfassen.

Die Schaffung von Lehrstühlen/Abteilungen/Sektionen im Bereich der Reproduktionsmedizin, Endokrinologie und Andrologie soll darüber hinaus bedeuten, dass der wissenschaftliche Nachwuchs sich auf diese Strukturen beziehen kann. Für Wissenschaftler würde es dadurch auch erstrebenswert sein, die Leitungen solcher Lehrstühle/ Abteilungen/Sektionen zu übernehmen, welches wiederum den Forschungsoutput fördern sollte. Letztlich sollte die Bundeärztekammer in die Überlegung mit einbeziehen, ob der Misere der Reproduktions- 
3. Actively approach foundations regarding research in human reproduction.

4. Since the concept of the role of foundations in the area of reproductive medicine is currently not well diffused, consideration should be given to whether initiatives should be taken to establish a German foundation for reproductive medicine.

5. This point in particular should be discussed by the Science Advisory Council of the German Medical Association.

\section{Controlling Authority}

The example of the Human Fertilisation and Embryology Authority (HFEA) in Britain indicates the positive aspects of an authority empowered to issue licences to centres and monitor the quality of these centres, while at the same time controlling aspects of human reproduction research. The British themselves, however, are questioning this solution. Nevertheless, it appears to have certain advantages, in particular when compared with a rigid embryo protection law. The Embryo Protection Law was implemented in 1991 in Germany and has since stood as a bastion of human reproduction law, although it has long been overtaken by progress in reproductive medicine.

A future reproductive medicine law would also address the question of regulation. There are two possibilities:

1. Central government authority. Similar to the HFEA, such a government authority would be incorporated into a reproductive medicine law and would regulate patient access, quality and licences as well as promote and direct research.

2. Voluntary quality assurance and certification through, for instance, the German Medical Association. Similar to the German Transplantation Law, consideration would have to be given to whether such an authority could be established by the German Medical Association through a reproductive medicine law. This should be discussed by the Science Advisory Council of the German Medical Association.

\section{Possibilities for Improving Research and Patient Care in the Area of Reproductive Medicine in Germany}

During the past twenty years, a dramatic change has taken place in reproductive medicine, marked by decreasing research activity and diminished presence of endocrinology, reproductive medicine and andrology in universities. This can and must be changed: Proposal 1: The universities should strive to establish departments, divisions or focal points in the areas of reproductive medicine, endocrinology and andrology. There are opportunities for establishing facilities in the area of gynaecology but interdisciplinary structures are also to be recommended.

Proposal 2: Universities should recognise that positive financial opportunities are available to them, since apart from payment via general medical care, a large portion of the services are paid personally by the patients, which has long been an economic benefit for private ambulant centres.

Proposal 3: The establishment of interdisciplinary departments and divisions for reproductive medicine would offer young scientists research opportunities, which would appear even more attractive if structural prerequisites are provided by departments, thus offering career opportunities. This would allow the threepronged model of the German Society of Gynaecology and Obstetrics to become a reality. medizin in Deutschland durch die Schaffung eines neuen interdisziplinären Weiterbildungsgangs Reproduktionsmedizin abgeholfen werden könnte.

Dies muss mit den zuständigen Fachgesellschaften DGGG, DGRM, DGA diskutiert werden.

\section{Förderprogramme}

Die Zurückhaltung der offiziellen Förderprogramme muss hinterfragt und aktiv eingegangen werden.

Nächste Schritte könnten sein:

1. Vorschlag an den Gesundheitsforschungsrat des BMBW (und BMG) für die Aufnahme der interdisziplinären Reproduktionsmedizin in das nächste Gesundheitsforschungsprogramm.

2. Hinterfragen der Strukturen der Max-Planck-Gesellschaft, Helmholtz-Gesellschaft, Leibniz-Gesellschaft bezüglich der Forschungsmöglichkeiten für menschliche Reproduktion.

3. Aktives Herangehen an die Stiftungen bez. Forschung der menschlichen Reproduktion.

4. Da zum jetzigen Zeitpunkt der Stiftergedanke für den Bereich der Reproduktionsmedizin wenig verbreitet ist, ist zu überlegen, ob Initiativen übernommen werden, eine deutsche Stiftung für Reproduktionsmedizin ins Leben zu rufen.

5. Insbesondere dieser Punkt sollte innerhalb des wissenschaftlichen Beirats der Bundesärztekammer diskutiert werden.

\section{Aufsichtsbehörde}

$\nabla$

Das Beispiel der englischen Behörde Human Fertilisation and Embryology Authority (HFEA) veranschaulicht, dass eine Behörde, die sowohl Lizenzierungen über die Zentren durchführt, diese Zentren qualitätsmäßig überwacht, aber zugleich auch Fragen der Forschung im Bereich der menschlichen Reproduktion regelt, positive Aspekte zeigt. Die englische Lösung wird von den Engländern selbst allerdings hinterfragt. Sie scheint aber dennoch einige Vorteile insbesondere gegenüber einem starren Embryonenschutzgesetz zu haben. Das Embryonenschutzgesetz wurde 1991 verabschiedet und steht seitdem wie ein Bollwerk, obwohl es von dem Fortschritt in der Reproduktionsmedizin längst überholt worden ist.

In einem zu schaffenden Fortpflanzungsmedizingesetz wäre daher auch die Frage der Regulierung zu klären. Hierbei ergeben sich 2 Möglichkeiten:

1. Zentrale staatliche Behörde. In Analogie zur HFEA wäre eine solche staatliche Behörde in einem Fortpflanzungsmedizingesetz festzuschreiben, die den Patientenzugang regelt, die Qualität beobachtet, Lizenzen für die Versorgung vergibt, sowie Forschung fördert und steuert.

2. Freiwillige Qualitätssicherung und Zertifizierung z.B. durch die Bundesärztekammer. In Analogie zum Transplantationsgesetz wäre auch zu überlegen, inwieweit eine solche Autorität durch ein Fortpflanzungsmedizingesetz bei der Bundesärztekammer angesiedelt werden kann. Dies müsste im wissenschaftlichen Beirat der Bundesärztekammer diskutiert werden.

\section{Perspektiven zur Verbesserung der Forschung und Patientenversorgung im Bereich der Reproduktionsmedizin in Deutschland $\nabla$}

In der Reproduktionsmedizin hat sich in den letzten 20 Jahren eine dramatische Veränderung gezeigt, die durch abnehmende Forschungsaktivität und abnehmende Präsenz der Bereiche Endokrino- 
Proposal 4: Structures should be created for research programs, actively including private centres. Cooperation with the relevant associations (BRZ, DGGG, DGRM, DGA, etc.) is of particular importance. The further development of stimulus programmes should give particular attention to the inclusion of care provided by private centres. Discussion should be held on encouraging other structures to provide financing of research projects and the creation of competence centres in the field of reproductive medicine. Proposal 5: A reproductive medicine law should also clarify whether quality assurance should be the responsibility of central structures such as HEFA in Britain or whether voluntary quality assurance and certification structures should be introduced by, for instance, the German Medical Association.

Proposal 6: The Embryo Protection Law should also be questioned from a political perspective because research that includes human embryos is currently prohibited in Germany.

\section{Conflict of Interest}

None.

Deutschsprachige Zusatzinformationen online abrufbar unter: www.thieme-connect.de/ejournals/toc/gebfra. logie, Reproduktionsmedizin und Andrologie an den Universitäten gekennzeichnet ist. Dieses muss und kann geändert werden:

These 1: Auf Seiten der Universitäten müssen Anstrengungen unternommen werden, Abteilungen, Sektionen oder Schwerpunkte für den Bereich der Reproduktionsmedizin, Endokrinologie und Andrologie zu bilden. Hier sind sowohl Möglichkeiten zu nutzen, die eine Ansiedlung im Bereich der Frauenheilkunde bieten, aber auch fächerübergreifende Strukturen sind empfehlenswert.

These 2: Die Universitäten sollten erkennen, dass auch für sie positive finanzielle Möglichkeiten vorhanden sind, da neben der Bezahlung über die Regelversorgung ein Großteil der Leistungen auf Selbstzahlerbasis abgerechnet werden kann, welches von den niedergelassenen ambulanten Zentren schon lange ökonomisch genutzt wird.

These 3: Die Einrichtung von interdisziplinären Abteilungen und Sektionen für Reproduktionsmedizin bietet zugleich jungen Wissenschaftlern die Möglichkeit der Forschung, die dann umso erstrebenswerter erscheint, wenn strukturelle Voraussetzungen durch Abteilungen da sind, sodass innerhalb dieser Abteilungen ihnen auch eine Karrieremöglichkeit geboten wird. Es gilt, das 3-Säulen-Modell der deutschen Gesellschaft für Gynäkologie und Geburtshilfe Realität werden zu lassen.

These 4: Für die Forschungsprogramme müssen Strukturen geschaffen werden, welche die niedergelassenen Zentren aktiv mit einbeziehen. Hier kommt der Kooperation der entsprechenden Verbände (BRZ, DGGG, DGRM, DGA etc.) eine besondere Bedeutung zu. Die Weiterentwicklung von Förderungsprogrammen muss den Einbezug der Versorgung durch Niedergelassene besonders beachten. Für welche weiteren Strukturen eine Finanzierung von Forschungsvorhaben, sowie eine Schaffung von Kompetenzzentren in der Reproduktionsmedizin angeregt werden könnte, muss diskutiert werden.

These 5: Im Rahmen eines Fortpflanzungsmedizingesetzes könnte auch geklärt werden, ob für die Qualitätssicherung eher zentrale Strukturen in Analogie zu Großbritannien (HEFA) oder Strukturen der freiwilligen Qualitätssicherung und Zertifizierung z.B. durch die Bundesärztekammer präferiert werden.

These 6: Politisch ist das Embryonenschutzgesetz auch in diesem Punkt zu hinterfragen, weil Forschung, die den menschlichen Embryo mit einbezieht, zum jetzigen Zeitpunkt in Deutschland verboten ist.

\section{Interessenkonflikt}

Nein. 